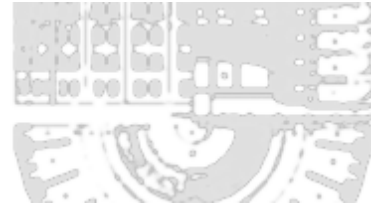 \\ Surveillance \& Society \\ \begin{tabular}{l|l} 
Article & $\begin{array}{l}\text { Prolepticon: Anticipatory Citizen Surveillance } \\
\text { of the Police }\end{array}$
\end{tabular}
}

\section{Ajay Singh}

Department of Sociology

University of Illinois at Urbana-Champaign, USA

asingh9@illinois.edu

\begin{abstract}
This paper introduces the concept of Prolepticon, describing anticipatory citizen surveillance of the police. Over the past four years, the spread of camera-enabled cellphones has allowed citizens to capture moments of police misconduct that previously would have remained unseen. The impact that this ubiquity of cellphone-wielding citizens has on policing is unclear. Former FBI Director James Comey suggests that the increased scrutiny on the actions of law enforcement through citizen video is causing police to retreat from policing, a phenomenon dubbed the YouTube Effect. I propose that as citizens continue to anticipate negative police-citizen encounters and record the interactions, and as officers internalize the potential of being surveilled by citizens, police are likely to moderate their behavior and engage in more professional policing. Through a series of case examples, I introduce the concept of Prolepticon using the Foucauldian lens of the Panopticon, providing a new paradigm to understand the impact of increased citizen surveillance of the police.
\end{abstract}

\section{Introduction}

\section{Defining the Issue}

Cellphone cameras are a ubiquitous reality in contemporary society. Users film everything from the food they eat to the trips they take, using the internet to share their experiences with a global audience. Although some uses of cellphone cameras are mundane, others can have real-world impacts beyond documenting one's culinary tastes. Some videos have the ability to change perceptions about the use and abuse of power in society, particularly between police and the citizenry. Citizens now possess the power to shed light on police practices in public space, providing the global community an opportunity to visualize the events as they unfold. Through these efforts, cellphone-wielding citizens are challenging institutionally driven narratives about encounters between citizens and the police, and increasingly disrupting the media's reliance on police as gatekeepers of information, something Lawrence (2000) refers to as "official dominance" (5).

One particular case highlights the power that citizen video has in challenging law enforcement driven narratives. On April 4th, 2015, in North Charleston, South Carolina, Officer Michael Slager pulled over Walter Scott for an alleged traffic violation. After a brief conversation, Mr. Scott fled the scene on foot while Officer Slager, also on foot, followed in pursuit. A brief altercation ensued and in a series of events, Officer Slager shot Mr. Scott several times, killing him. The story told by police and the media after the 
shooting reflected thousands of similar stories told over the years following police shootings: the officer feared for his life and only shot the suspect as a last resort. Indeed, the news story in a South Carolina newspaper released the day of the shooting repeated this police narrative:

A statement released by North Charleston police spokesman Spencer Pryor said a man ran on foot from the traffic stop and an officer deployed his department-issued Taser in an attempt to stop him. That did not work, police said, and an altercation ensued as the men struggled over the device. Police allege that during the struggle the man gained control of the Taser and attempted to use it against the officer. The officer then resorted to his service weapon and shot him, police alleged. ... Officers tried to revive him prior to the arrival of paramedics, police said. But their efforts were in vain. He was pronounced dead at the scene, authorities said. Police did not immediately specify whether he was armed. (Elmore and MacDougall 2015)

Other news reports repeated this story uncritically with no mention of any counternarrative (ABC4News 2015; Knapp 2015a). Although Officer Slager's dash camera caught some of the initial interaction, the subsequent events, the struggle and the shooting, occurred outside the range of the camera, and the officer was not equipped with a body worn camera system (Silva 2015). Officer Slager released a statement through his lawyer the following day claiming that Mr. Scott attempted to wrestle his Taser from him and he shot Mr. Scott as a last resort, fearing for his life (Knapp 2015a). For most cases, a lengthy investigation would follow, the department would relegate the officer to administrative duties and the existing narrative would stand while the public waited months or years for a decision on the legitimacy of the shooting. However, this case was different.

Feidin Santana was on his way to work that morning when he came across Officer Slager chasing Mr. Scott into a clearing. Anticipating a need to film, he decided to pull out his phone and record their interaction (Laughland and Swaine 2015). On the footage, he captured Mr. Scott, with Taser probes attached, breaking away from Officer Slager. Officer Slager calmly pulls out his service weapon and while Mr. Scott continues to flee, now at least fifteen feet away from the officer, shoots him eight times in the back, killing him. Officer Slager walks over to Mr. Scott's body, places him in handcuffs, jogs back to his initial firing location, picks up an object, calmly walks back to Mr. Scott's body and drops the item next to him. Contrary to the initial news reports, not one of the officers arriving on scene renders medical aid to Mr. Scott. By April 7th, three days after the shooting, prosecutors charged Officer Slager with murder (Knapp 2015b).

The charging of Officer Slager for murder following the release of the cellphone footage highlights the power that citizen-initiated surveillance of the police can have in changing law enforcement driven narratives on police shootings. This video, along with countless others, are bringing increased scrutiny to the actions of law enforcement that is fundamentally different from traditional methods of surveilling the interactions between police and the citizenry, like dash cameras and body cameras. Citizens are now anticipating police misconduct and, in a moment's notice, recording the behavior of the police in public space and altering the normative relationship of power between the citizenry and the police.

This changing relationship is impacting the very act of policing in the U.S. However, its impacts are unclear. Responding to suggestions of rising violent crime rates in major U.S. cities, law enforcement officials like former FBI director James Comey argue that officers are not being as proactive in their policing, fearing someone will record and upload their encounters with the citizenry to the internet (Schmidt and Apuzzo 2015). This perspective, articulated by Comey, New York City Police Commissioner William Bratton and Chicago Mayor Rahm Emanual is known as the Ferguson or YouTube Effect (Davis 2015; Sanchez 2015). Others suggest that this increased scrutiny of police actions is forcing departments to enter into agreements with groups like the American Civil Liberties Union, 
requiring officers to document citizen stops more thoroughly than was previously required. Dubbing the phenomena the ACLU effect, officers in the City of Chicago suggest that these requirements are too onerous, leading to a decline in citizen stops and an increase in gun related violence (Main 2016). However, I suggest an alternative framework, positing that as cellphone-enabled citizens continue to anticipate negative police encounters and film the actions of law enforcement, with the footage remaining in control of the citizen who then use the internet to propagate these videos around the world, they are creating an environment where officers no longer know if they are being surveilled, leading police to become self-disciplining subjects. I call this new policing environment the Prolepticon. This paper explores this issue through the Foucauldian lens of the Panopticon and an examination of case examples to provide insights into ways that citizens can engage in resistance activities through the anticipatory filming of interactions between police and the citizenry in the United States, changing the narrative and coverage of police-citizen interactions and influencing those in a position of power to become self-disciplining subjects.

\section{Method of Presentation}

I first explore the construction of the Panopticon as envisioned by Bentham and Foucault. Moreover, I examine the usage of the Panopticon in contemporary surveillance literature, describing its application to the internet, the workforce, and, more importantly, as a tool to challenge those in a position of power. With this literature in mind, I then provide an in-depth discussion on the concept of the Prolepticon, discussing its meaning, the variety of actors associated with this type of surveillance, the influence it has to augment relationships of power, the role of citizen video in challenging police-driven narratives and the utilization of information technologies in facilitating the Prolepticon. I follow this with some of the challenges that may prevent the realization of proleptical environments, including the lack of punishment for officers who engage in acts of abuse and the importance of space in creating the perception of omnipresent surveillance. I conclude with recommendations for future areas of research and what needs to be done to better understand this new environment of policing.

\section{Literature Review}

\section{The Panopticon}

The idea of being surveilled as a means to create self-disciplining subjects is a hallmark of the Panopticon. The Panopticon, first introduced by Jeremy Bentham, has provided for the social sciences great insight into the tangled relationships of hierarchy, power and discipline. Michel Foucault utilized elements of the panoptic design to give greater insight into the field of medicine, including the management of epidemics and plagues in the late $17^{\text {th }}$ and $18^{\text {th }}$ centuries, the design and spatial arrangement of hospitals and the general management of public health (Elden 2002). He used the Panopticon to describe the transition from punishment inflicted on the individual's body in open, publicly viewable space, to something that relied on building systems of soul training, normalized through everyday practices, consisting of techniques that shape and cultivate a self-disciplining individual (Foucault 1977).

For Bentham, he viewed the Panopticon as a means to provide uniform supervision over the prison population and as the preeminent design for developing self-disciplining prisoners while utilizing minimum amounts of labor (Bentham and Bezovic 1995). The architecture of the building reflected this goal. He described the building as of circular construction, with cells occupying the outer edges, each cell secluded from the others, preventing any means of communication between prisoners. Each cell also contained a small window, letting in enough light to illuminate the prisoner while preventing them from seeing outside of their confines. A raised inspector's lodge occupied the center of the design, with space between the cells and the inspector's lodge. The inspector maintained the ability to see into each cell but the prisoner could not confirm if the inspector was indeed watching.

In describing the effects of panoptic penitentiary houses, Bentham suggested that 
the more constantly the persons to be inspected are under the eyes of the persons who should inspect them, the more perfectly will the purpose of the establishment have been attained. Ideal perfection, if that were the object, would require that each person should actually be in that predicament, during every instant of time. That being impossible, the next thing to be wished for is, that, at every instant, seeing reason to believe as much, and not being able to satisfy himself to the contrary, he should conceive himself to be so. (Bentham and Bezovic 1995: 34)

Bentham's description is clear that that not all prisoners need to be monitored at all times; rather they should believe that there is a possibility that their actions are being monitored. The effect of this system is that given the prisoner's inability to determine if they are being watched, they will self-discipline their behavior for fear of being caught and receiving a reprimand for violating rules and regulations of the institution.

Although Bentham did not live to see wide-scale adoption of panoptically styled penal institutions (Boyne 2000; Murakami Wood 2007), Foucault found many characteristics of the Panopticon that reflected other areas of society in which hierarchical notions of surveillance are applicable, like schools, hospitals and workplaces. Indeed, he described it as "a figure of political technology that may and must be detached from any specific use" (Foucault 1977: 205). For Foucault, panoptic systems of surveillance expose individuals to a spectrum of visibility that ensures an anticipated functioning of power: the individual who "knows it, assumes responsibility for the constraints of power; he makes them play spontaneously upon himself; he inscribes in himself the power relation in which he simultaneously plays both roles; he becomes the principle of his own subjection" (Foucault 1977: 203). The process of the Panopticon then acts as a form of soul training, a disciplining process allowing the individual being watched to impose the constraints of normative expectations onto themselves without the watcher needing to physically intervene. Individuals know they are being watched, and not wanting to expose themselves to potential disciplinary action, constrains their behavior.

\section{The Panopticon and Surveillance Studies}

Despite the bygone origins of the Panopticon, the current literature in Surveillance Studies continues to utilize the panoptic model, providing insights into processes associated with contemporary systems of surveillance. While there is a segment of the literature that suggests the importance of the Panopticon is diminishing (Haggerty 2006; Haggerty and Ericson 2000; Lyon 2006), a non-trivial amount of the literature continues to look to the Panopticon for perspectives on how the perception of being surveilled may lead to self-disciplining behavior.

For example, Brignall (2002) uses the Panopticon to describe characteristics of the internet that allow for clandestine monitoring of user behavior by both government and private sector agents. As users become aware of this surveillance, they either curtail their online behavior or search for methods to bypass this type of surveillance. Likewise, Tsui (2003) examines the panoptic characteristics of the internet and the exploitation of these facets by the Chinese government to monitor its citizens and limit the type of information they may encounter. Citizen awareness of these systems can then lead to self-restricting behavior. Berdayes (2002) sees characteristics of panoptic rationales diffused throughout the literature on approaches to organizational management, focusing on systems that create self-disciplining workers, with the worker under the impression that they may be watched at any given time. Similarly, Fernie and Metcalf (1999) describe the panoptic features of computer management systems in call centers which allow managers to monitor their employees, provide evaluation metrics on their performance and implement total control software packages to influence the workers' behavior. Fan (2012) examines the usage of dataveillance, or the monitoring and recording of "people's activities or communications in an automated way, using information technologies" (Lyon 2007: 4) to drive police reforms, limit the occurrence of officer abuse and create self-disciplining officers. This perspective, dubbed panopticism for 
the police, includes tracking data like citizen stops and use of force complaints, which can provide warning flags against officers who abuse their power. The officer's awareness of such a system is said to drive self-disciplining behavior.

While the aforementioned literature examines traditional hierarchical systems of surveillance, other authors have turned notions of the Panopticon on its head. Indeed, these authors have used an inverse model of the Panopticon to provide insights into various aspects of citizen-centric surveillance of traditional power institutions. In introducing the synopticon, Mathiesen (1997) describes situations "where a large number focuses on something in common which is condensed. . . it may stand for the opposite of the situation where the few see the many" (219). He uses the synopticon to describe increases in mass media and the widespread distribution of information channels that allow many viewers to focus on a singular object, as with mass sporting events, which reflect what he calls a viewer society. In his piece on citizen surveillance of police during protests, Clarke (2013) examines the intersection of cellphone videos and the internet in spreading awareness about abuses of power, with a focus on the 2011 November incident at the University of California, Davis, where students filmed an officer pepper spraying nonviolent, passively resisting protestors. While Clarke tends to emphasize the role cellphone technology has on documenting instances of abuse, he oddly leaves the notion of self-disciplining subjects out of his analysis; he does not address how cellphone activism may actually change the behavior of those in power. A variation of the Panopticon most closely associated with the concept of Prolepticon is the idea of sousveillance. Mann, Nolan and Wellman (2002) use the term to describe those that watch from below, explicitly labelling the concept as an inverse Panopticon. The authors present the concept as a form of reflectionism, or the "philosophy and procedures of using technology to mirror and confront bureaucratic organizations" (Mann et al. 2002: 333). Within this construct, the authors see sousveillance as related to the idea of detournement, or "the tactic of appropriating tools of social controllers and resituating these tools in a disorienting manner" (Mann et al. 2002: 333). Citizens who engage in acts of surveillance against the police participate in both acts of reflectionism and detournement: using information technologies and actions of surveillance to guide officers back towards the normative expectations of policing. One can then situate the Prolepticon within the concept of sousveillance. In other words, the proleptical environment is a niche application of sousveillance. While Mann et al. use the concept to broadly define situations where countersurveillance from below takes place utilizing the technology of the oppressor, I use the concept of the Prolepticon to specifically articulate the ways that those who anticipate negative interactions between the police and the citizenry and record the police can bring greater transparency and accountability to the act of policing while, in the process, effectuate an environment that creates self-disciplining police officers.

\section{The Prolepticon}

\section{Definition and Description}

When a citizen brandishes a cellphone camera and records the interactions between police and the citizenry, anticipating a negative interaction, the act represents an action of defiance, resistance and selfempowerment, intentionality aside. Individuals who decide to record the police are purposeful actors, whose action is an attempt to document and/or shape the interaction taking place in such a way that it challenges normative understandings of power in the relationship between police and citizens. Particularly in high-density spaces, camera enabled citizens are omnipresent, leaving officers exposed to the persisting possibility of being surveilled. This environment of contemporary policing, where police do not have the expectation of privacy and the possibility exists that their actions may be recorded by citizens, where the produced footage remains outside of police control in a way that may cause officers to discipline their behavior, is what I call the Prolepticon. ${ }^{1}$ I suggest that the greater likelihood that a civilian is going to record the actions of the police and potentially share the video with a wide audience, the more likely

${ }^{1}$ The root of Prolepticon, proleptical, means "in anticipation of." 
officers will internalize that possibility and discipline their own behavior. This new form of civilian initiated, anticipatory surveillance of the police alters traditional boundaries of power where previously, control of surveillance footage (dashboard cameras and body worn camera systems) remained firmly in the grips of law enforcement, allowing the police to dictate the video's release and establish control of the media narrative, which tends to prioritize law enforcement framing of citizen-police encounters (Lawrence 2000). It is the cellphone, wielded by citizens, that produces the greater likelihood for the "automatic functioning of power" (Foucault 1977: 201), providing more credibility to counternarratives. The cellphone then acts as a disciplinary instrument, where the produced footage renders visible the actions of the police, functioning so that control of the footage remains in the hands of the less powerful. In this way, these cellphone activists alter the hierarchically normative relations of power, challenge predominant police driven narratives and transform "the whole social body into a field of perception" (Foucault 1977: 214).

\section{Actors and Relationships of Power}

The phrase cellphone activist does not suggest that all actors are dedicated activists whose intent is to shape the interactions between police and the citizenry. Although some social activists purposively follow and record the actions of the police in public space, ordinary citizens can also happen upon a situation and feel compelled to record the interaction. In both instances, the citizen is anticipating an interaction that requires video documentation. It is also the case that those involved with the police in an interaction may decide that they should record the encounter to document the nature of the interaction. However, the impact of the individual who records the police, whether they identify as an activist or not, is still the same: officers may self-discipline their behavior for fear that someone outside of their control may record their interaction with a citizen and upload the video to the internet.

While some choose to record the police surreptitiously, positioning themselves so that the officer does not know they are being recorded, others do so conspicuously, in plain view of the officer. Conspicuous visibility is problematic in traditional panoptically designed spaces under the rationale that "the less the inspector is really present, the more he is apparently omnipresent; or, more precisely, the inspector is apparently omnipresent precisely insofar as he is not really present, since a momentary exposure to the eyes of the prisoners is sufficient for him to lose his apparent omnipresence. Here, then, appearance precludes reality" (Bentham and Bozovic 1995: 9). However, this is not problematic for proleptical environments, as no central watcher exists. Within proleptical environments, there are many potential anticipatory watchers and the confirmation of one does not limit the possibility of others and thus, the potential of omnipresent supervision still exists.

Systems of surveillance are predicated upon a differing level of power between the watcher and those being watched (Gilliom 2001). Traditionally, police maintain significant power over the citizen. They have the ability to arrest members of the citizenry and are granted the ability, under specific circumstances, to take the life of a citizen. However, citizen surveillance of the police disrupts this hierarchical power association by exposing abusive police behavior to a set of societal norms and exposing the officer to potential punitive repercussions. For every citizen that captures an officer's abusive behavior on film, resulting in punitive actions against the officer, it reshapes the power relationship between police and the citizenry.

As citizens take part in practices that reshape unidirectional power dynamics with the police, they subject themselves to the possibility of facing retaliatory actions from the police who view these efforts as a challenge to their authority, despite the legal rights citizens have to record officers in public spaces, provided they are not interfering with any law enforcement action (ACLU 2015). This retaliation occurs in several different ways: police officers attempting to confiscate phones while the citizen records, attempting to destroy the footage or the phone, threatening arrest of the citizen or directing harassment to those known by the police to have engaged in proleptical surveillance. For example, police in Miami, 
Florida attempted to confiscate the phone of a citizen who was recording the police punch a subdued suspect. When she did not comply, they threatened to place her under arrest unless she deleted the footage (Phillip 2015). Police confiscated the phone of a citizen in Denver, Colorado who was recording the police arrest several protestors in an incident in 2015 (Mitchell 2016). Ramsey Orta filmed police choking and killing Eric Garner in 2014 July in New York. The footage of his killing went viral and Orta and his family describe persistent harassment from the New York Police Department as a result (Sanburn 2015). It is clear that the actions taken by law enforcement directly challenge the citizen's ability to record policecitizen interactions in public. Moreover, these actions by law enforcement attempt to restore the perceived usurpation of power from the police, by the citizen. These unlawful actions by law enforcement are a direct attempt to not only limit the recording that is taking place, but deter other citizens who may decide to record the actions of the police in the future.

\section{Power of Citizen Video}

Perhaps the most widely known example showing the power of citizen surveillance of the police is the video that captured the beating of Rodney King. On March 3rd, 1991, George Holliday, using his newly purchased video camera, captured 15 police officers beating Rodney King on a street in Lakeview Terrace, Los Angeles. King suffered a concussion and fractures to his skull, eye socket and cheek, leaving his face partially paralyzed (Mydans, Stevenson and Egan 1991). The police maintained that King charged the officers after being stopped for speeding and continued to resist arrest before being detained. However, the video showed a man on the ground, in a prone position, beaten repeatedly by three officers using their legs and batons, while twelve other officers stood by and watched. The video did not show King offering the type of resistance suggested by the police narrative of the incident.

Holliday's video crystalized in visual form what had previously been relayed through witness and victim accounts and served as the impetus to legitimize the conversation amongst policy makers about the prevalence of police brutality around the country during a time when accusations of police abuse in minority communities were especially prevalent. ${ }^{2}$ Without the video and its widespread dissemination, it is highly likely that King would suffer the same fate as many before him: the police would charge King with resisting arrest and battery against an officer, with the argument that the injuries suffered by King were the result of the officers' attempts to subdue him. Indeed, even after the release of the video, the police insisted that the district attorney pursue these very charges against King (Mydans et al. 1991). The DA subsequently declined and King was released from police custody.

Comparing the Holliday video to videos captured by cellphones provide intriguing contrasts and comparisons. First, the likelihood of a citizen capturing this type of footage using a video camera was very small. Holiday happened to have just purchased the camera, and the Los Angeles Police Department brazenly conducted the beating in front of residential complexes and several eyewitnesses. If the beating took place in a far less occupied space, away from the view of homes, it is very likely that this video would not exist. Second, multiple officials within the LAPD, including chief of police Daryl Gates, argued that the video was an aberration and not indicative of the actions of the LAPD or police in general (Lawrence 2000; Mydans 1991). Unlike the King video, cellphone footage showing police violence in jurisdictions across the country makes it difficult to argue that incidents like the King beating are isolated incidents. Citizens are not beholden to media entities to share the video; they can rely on social media and the internet to spread the video and create pressure to take action against the offending officer, something Miller (2016) calls viral accountability. However, both the Holliday video and videos taken by cellphones share a very important similarity: both videos remained in the hands of the citizens, allowing them to dictate where, when and under what conditions the video is made available to the public. By doing so,

\footnotetext{
${ }^{2}$ For example, settled lawsuits by the LAPD rose from $\$ 553,000$ in 1972 to $\$ 8$ million in 1990 (Mydans et al.
} 1991). 
they are challenging initial media depictions about these interactions which have typically relied on the perspective of law enforcement to the detriment of other perspectives (Lawrence 2000).

\section{Cellphones Across America}

The nascent ability to challenge police-driven narratives in the United States is made possible through the spread of camera-enabled cellphones amongst citizenry. Over the last 15 years, cellphone ownership amongst Americans aged 18 years or older rose from 53 percent in the summer of 2000 to a staggering 92 percent by April 2015 (Pew Research Center 2015). Relatedly, the rate of those who do not own any type of cellphone is declining, from 17 percent in 2011 to 10 percent in 2014 (Pew Research Center 2014). Moreover, smartphones, hybrid devices that combine many elements of a personal computer with a phone that allows the user to have access to the internet and web based application (Portokalidis, Homburg, Anagnostakis and Bos 2010), are increasingly becoming more ubiquitous amongst the American population. Between 2011 and 2015, smartphone ownership amongst American adults rose from 35 percent to 68 percent. Most smartphones are connected to the internet at all times, either through Wi-Fi connections or mobile connections with a service provider, allowing the user access to cloud storage, a complex of servers that stores data in a remote location.

With this arrangement for storage, when a user takes a video or an image, the recording is immediately saved not only on the phone's hard drive or memory unit, but also in the cloud. This prevents officers from destroying the footage through destruction of the device, confiscation of the phone or forcing the user to delete the footage, as in the 2012 August case in New York where police confiscated the phone of a citizen who had filmed the police shooting of a man in Times Square (Schwirtz and Edwards 2012). A similar incident unfolded in Antioch, California in 2014 August, where officers confiscated and deleted footage from the phones of multiple witnesses who observed police roughly arresting another citizen (Wang 2014). If the user does delete the footage from any local storage on the phone, the footage will still exist in the cloud. ${ }^{3}$

This is not to say that smartphones do not have issues impacting their ability to capture the interactions between police and the citizenry. First, the user must have set up their cloud service before taking the footage. This is a preeminent concern, as the lack of cloud services allow for any officer to confiscate the phone and delete the footage, or force the user to delete the footage with no backup. The knowledge that cloud services exist and the subsequent process in setting up an account is a key piece of information that not all citizens possess. This is reflective of a digital divide amongst users, with some users not having the knowledge about how best to utilize that technology and exploit all of its potential (Selwyn 2004). Second, the footage may become obscured during the incident, minimizing the footage's effectiveness to show the events taking place. The average citizen is not a professional photographer and the lack of experience in recording footage, particularly in emotionally intensive situations like witnessing police abuse, may cause the user to produce shaky footage that obfuscates more than it elucidates. In spite of the technological limitations of the cellphone and smartphone, the Prolepticon functions not through the actual production of video from these tools, but the officer's perception that their actions may be recorded by someone that they either cannot see or cannot control, causing them to moderate their behavior.

The growth of information technologies over the last decade facilitates awareness about incidents of police abuse around the world. This increasing connectedness between the local and the global through the expansion of information technologies, something David Harvey refers to as time-space compression (Harvey 2005), is fundamentally changing the way that actors in different parts of the world understand their struggle relative to other groups. Incidents that were once a local story, traditionally limited to the

\footnotetext{
${ }^{3}$ I should note that some phones link the deletion of an item from one source to the deletion of the same item stored at a separate location. Meaning, if an officer deletes the image from the local source, the phone may prompt the user to delete the same footage from all stored locations.
} 
crime section of the print edition in the local paper, becomes part of a national story about the prevalence of police abuse and part of the global conversation relating to the resistance of marginalized groups against institutions of power. Official efforts to relegate the occurrence of police misconduct to a few bad apples becomes more problematic when videos from around the United States show officers engaging in acts of brutality (Lawrence 2000). The internet facilitates the increase in pressure on municipalities to prosecute officers who are recorded engaging in acts of police abuse. While this does not guarantee punishment for occurrences of police misconduct, it does increase the level of scrutiny and the likelihood that officers will experience shame, firing and potentially incarceration for their actions.

Cellphone footage has played integral roles in the dissemination of video that documents police misconduct, from incidents of police brutality to the shooting and killing of citizens, which have had broad societal impacts. Although the 2014 July killing of Eric Garner in New York did not result in any charges against the officer, the video and Garner's last words, "I can't breathe," became a symbol for what became known as Black Lives Matter, a social movement attempting to draw attention to the disproportionate acts of police brutality against African Americans in the United States (Cave and Oliver 2015). Cellphone footage from a 2015 June incident in Texas showed an officer pulling a gun on several teens as they responded to a call about a disturbance (Pengelly 2015). Video from the encounter resulted in the officer resigning from his position (Weber 2015). Cellphone footage from 2016 July showed police shooting and killing Alton Sterling in Baton Rouge, Louisiana (Shoichet, Berlinger and Almasy 2016). One day later, police shot and killed Philando Castile in Saint Paul, Minnesota while his girlfriend livestreamed the aftermath on Facebook (Croft 2017). The shooting deaths of Sterling and Castile led to a series of global protests against acts of police brutality (Fantz and Visser 2016). The aforementioned videos, in addition to countless others, become part of the narrative of police violence in the United States and serves as a visual check on police-driven narratives about the prevalence of police violence. The cacophony of videos taken from various social settings creates the perception in officers' minds that their actions may be recorded at any time, regardless of their jurisdiction. This is the power that citizens recording the police has on transparency and the push to reform policies dealing with the ways that police interact with the citizenry.

\section{Obstacles to the Prolepticon}

According to Foucault, panoptic environments function partly through the usage of space relative to the watcher and through the potential of punishment for those that violate established rules and norms (Foucault 1977; Koskela 2002). However, these two components are problematic when conceptualizing the Prolepticon. The likelihood of a citizen being present and having access to a cellphone increases as the population density of a particular area increases. While urban spaces have a higher density of people and cellphones, both of which facilitate proleptical environments, police who patrol primarily rural areas are far less likely to encounter a citizen who may be surreptitiously recording them. Moreover, officers are far less likely to perceive the possibility that they may be recorded by a third party observer and may not be as cautious in their interactions with citizens in public space. While this currently may be a limiting factor for rural areas, moving forward, the number of citizens possessing cellphones with high quality video cameras will continue to increase in both rural and urban areas, suggesting that this particular constraining factor will decrease over time.

More problematic for the functioning of proleptical environments is the lack of punishment officers face if they violate norms and expectations of good policing (Futterman and Kalven 2007). Internal investigations of citizen complaints rarely result in actions taken against offending officers (Bichao 2014). For example, in 2002, about 92 percent of all cases involving accusations of excessive force throughout the United States resulted in no action taken against the officer (Bureau of Justice Statistics 2006). Moreover, if district attorneys consider criminal charges, they very rarely file them against the officer. Indeed, in 2005, prosecutors declined charging officers in 98 percent of cases where investigative agencies suggested reasonable grounds existed for prosecution (Johnson 2007). For those situations that make their 
way to trial, jurors are highly unlikely to find officers criminally liable for their actions in the field, viewing the police in a generally positive light (Jones 2015). In the rare occurrence of a jury convicting the officer for acts of misconduct, the penalty is generally very minimal, with officers rarely receiving little, if any jail time. Of the fifty-four officers charged with some crime for the thousands of policeinitiated shootings since 2005, only eleven were convicted, with penalties ranging from deferred convictions to ten years in prison, with an average sentence of three and a half years (Kindy and Kimbriell 2015). However, as citizens continue to put pressure on investigative agencies to charge abusive officers, supported by the presence of video evidence that documents the acts of abuse, these institutions must make the decision to either risk losing legitimacy in the eyes of the citizenry or continue to protect the abusive actions of the police. As the Walter Scott case demonstrated, video evidence that clearly captures acts of police abuse can lead to concrete action by legal authorities.

Although citizens have the option of pursuing civil litigation against the officer accused of misconduct, the payout for sustained grievances comes from either an insurance policy or from the municipality (Collins 1998). Taxpayers and insurance policies have footed the cost of civil litigation from police brutality, paying out more than a billion dollars. For example, between 1994 and 1996, New York City paid out around $\$ 70$ million dollars to settle misconduct lawsuits; the city of Los Angeles paid \$79.2 million dollars between 1991 and 1996 (Collins 1998). Between 2010 and 2015, the ten cities with the largest police forces paid over $\$ 1.02$ billion dollars to settle lawsuits for police misconduct (Elinson and Frosch 2015). Rarely do officers pay directly for acts of misconduct. The lack of potential repercussions, even if acts of abuse are caught on camera, may problematize the functioning of proleptical environments. However, in this regard, the landscape may be changing. Insurers are increasingly shaping reform in police agencies across the country, placing greater restrictions on the types of actions that police perform, the manner in which they perform them and the types of coverage that they offer municipalities (Rappaport 2017). Police agencies, in the age of increasing budgetary restrictions, must engage in risk and efficiency management strategies that, in effect, can encourage them to proactively police those officers who engage in acts of abuse for fear of greater economic constraints (Police Executive Research Forum (PERF) and the United States of America 2013).

In spite of concerns about the lack of cameras and people in rural spaces and the lack of punishments for officers who engage in acts of abuse, society is merely entering the age of the Prolepticon. As cellphone use expands and camera technology improves, global society becomes more interconnected. Each case that gains notoriety due to citizen video increases the likelihood that officers will internalize the possibility that their actions in public space are being supervised by someone outside of their control. Dashboard and body-worn camera systems are no longer the sole visual narrative of an interaction between the police and the citizenry and corporate media are increasingly presenting critical alternatives to traditionally accepted police narratives (Lawrence 2000). The Walter Scott shooting shows how quickly authorities can act when presented with a visual narrative that challenges police descriptions of an incident. The statistics highlighting the lack of charges and convictions against officer abuse are going to be challenged more so than at any point in police history. Pressure will continue to increase on investigative agencies and legal institutions to hold officers accountable for videos that clearly show police abuse.

\section{Moving the Conversation Forward}

\section{Directions for Future Research}

Police in the United States are currently facing an unprecedented level of scrutiny towards the act of policing, and cellphone videos that highlight acts of police abuse play a large role in this. When a citizen films an act of police abuse and uploads that video to the internet, people around the world immediately gain access to those images that challenge the narrative offered by institutions of power. This increased scrutiny is impacting the very act of policing; however these effects are very unclear. There are various suggestions by those in law enforcement that these videos and scrutiny are causing officers to pull back 
from the field for fear of having their actions videotaped and spread around the world, a concept known as the YouTube effect. In this paper I suggest an alternative framework of the Prolepticon, where officers are increasingly self-disciplining their behavior for fear of being filmed. However, both of these potentials are, as of this writing, unsubstantiated.

Moving this research forward will require efforts directed towards interviews with officers in the field, who can provide differing perspectives from that of mayors, union representatives and law enforcement officials higher in the police hierarchy, and participant observation through ride-alongs, allowing researchers to view how officers react to being filmed by citizens. These methods can address how conscious officers are of being filmed, either by dashboard cameras and/or body cameras, if they perceive a difference between these types of traditional surveillance apparatuses and the footage created by cellphone-wielding citizens and if they augment their behavior when being filmed. Moreover, police can provide emic perspectives on the impact that these types of surveillance have during their day-to-day interactions with the public, including how the potential misuse of video footage by citizens may play into police perceptions about a war on the police. It is also essential that interviewed officers come from a cross-section of differing population densities to explore the issue of space and the perception of being watched. While this paper focuses on actions of the police in the United States, further research on policing practices around the world could provide a more complete picture about how these surveillance apparatuses are impacting policing in general, as the dynamics of policing in the US are far different than other countries, both in their history and practice. Additionally, researchers should examine training materials and other bureaucratic manuals that can show if the issue of cellphone-wielding citizens is making its way into instructional materials for the officer in the field. Having knowledge of how police academies prepare officers in the field to deal with civilians recording their actions will help explain the origins of the different types of retaliation civilians' face and how officer training is preparing, or not preparing, officers to deal with this new environment of policing.

Furthermore, the usage of cellphone cameras is increasingly playing a role during protests directed towards social and political causes. Interviews with activists could shed light on how readily they view proleptical surveillance as a tool for not only holding officers accountable for abuse that occurs, but also shaping the behavior of the officers to prevent abuse from happening in the first place. If the impacts of the Prolepticon are substantiated in fieldwork, then this type of surveillance against police and other actors of power represents a pathway forward for activists across the political spectrum to not only hold actors accountable for specific abusive behavior, but actually change the way that these actors interact with the citizenry. In this way, future research can provide valuable information not only to law enforcement officials about the impacts of increased scrutiny on the actions of the police, but also serve as a guide for citizens who feel they do not have the means to challenge abuses by the police within their communities.

\section{Acknowledgments}

I would like to thank Asef Bayat, Behrooz Ghamari Tabrizi and Anna Maria Marshall for their review of this article.

\section{References}

ABC4News. 2015. SLED investigating officer-involved shooting in North Charleston that stemmed from traffic stop. ABC4News, April 4. http://abcnews4.com/archive/officers-respond-to-traffic-incident-witnesses-call-shooting-in-north-charleston.

ACLU. 2015. Know your rights: Photographers-what to do if you are stopped or detained for taking photographs. https://www.aclu.org/know-your-rights/photographers-what-do-if-you-are-stopped-or-detained-takingphotographs?redirect=know-your-rights-photographers.

Bentham, Jeremy and Miran Bozovic. 1995. The panopticon writings. London: Verso.

Berdayes, Vicente. 2002. Traditional management theory as panoptic discourse: language and the constitution of somatic flows. Culture and Organization 8(1): 35-49.

Bichao, Sergio. 2014. Central Jersey police departments uphold just 1\% of excessive force complaints. My Central Jersey, November $\quad 18 . \quad$ http://www.mycentraljersey.com/story/news/2014/08/10/nj-use-of-force-internal-affairsinvestigations/13822965/. 
Boyne, Roy. 2000. Post-panopticism. Economy and Society 29(2): 285-307.

Brignall, Tom. 2002. The new panopticon: The Internet viewed as a structure of social control. Theory \& Science 3 (1): 15271558.

Bureau of Justice Statistics. 2006. Citizens complained more than 26,000 times in 2002 about excessive police force. Bureau of Justice Statistics, June 25. http://www.bjs.gov/content/pub/press/ccpufpr.cfm.

Cave, Damian and Rochelle Oliver. 2015. The Videos That Are Putting Race and Policing Into Sharp Relief. The New York Times, November 24. http://www.nytimes.com/interactive/2015/07/30/us/police-videos-race.html.

Clarke, Stephen. 2013. The Panopticon of the Public Protest: Technology and Surveillance. Res Cogitans 4(1): 173-180.

Collins, Allyson. 1998. Shielded from justice: Police brutality and accountability in the United States. New York: Human Rights Watch.

Croft, Jay. 2017. Philando Castile shooting: Dashcam video shows rapid events. CNN, June 21.http://www.cnn.com/2017/06/20/us/philando-castile-shooting-dashcam/index.html.

Davis, Aaron C. 2015. "YouTube effect" has left police officers under siege, law enforcement leaders say. The Washington Post, October 8. https://www.washingtonpost.com/news/post-nation/wp/2015/10/08/youtube-effect-has-left-police-officersunder-siege-law-enforcement-leaders-say/.

Elden, Stuart. 2002. Plague, panopticon, police. Surveillance \& Society 1(3): 240-253.

Elmore, Christina and David MacDougall. 2015. Man shot and killed by North Charleston police officer after traffic stop; sled investigating. The Post and Courier, April 4. http://www.postandcourier.com/article/20150404/PC16/150409635.

Elinson, Zusha and Dan Frosch. 2015. Cost of Police Misconduct Cases Soars in Big U.S Cities. The Wall Street Journal, July 15. http://www.wsj.com/articles/cost-of-police-misconduct-cases-soars-in-big-u-s-cities-1437013834.

Fan, Mary D. 2012. Panopticism for Police: Structural Reform Bargaining and Police Regulation by Data-Driven Surveillance. Washington Law Review 87: 93-138.

Fantz, Ashley and Steve Visser. 2016. Hundreds arrested in protests over shootings by police. CNN, August 4. http://www.cnn.com/2016/07/10/us/black-lives-matter-protests/index.html.

Fernie, Sue, and David Metcalf. 1999. (Not) hanging on the telephone: payment systems in the new sweatshops. Advances in industrial and labor relations 9: 23-68.

Foucault, Michel. 1977. Discipline and punish: The birth of the prison. New York: Vintage.

Futterman, Craig B. and Jamie Kalven. 2007. The need for independent civilian review of the Chicago police department. The University of Chicago Law $\quad$ School, $\quad$ April https:/www.law.northwestern.edu/legalclinic/macarthur/projects/police/documents/CivReviewPreamble.pdf.

Gilliom, John. 2001. Overseers of the poor: Surveillance, resistance, and the limits of privacy. Chicago, IL: University of Chicago Press.

Haggerty, Kevin D. 2006. Tear down the walls: on demolishing the panopticon. Theorizing surveillance: The panopticon and beyond, edited by David Lyon, 23-45. London: Routledge.

Haggerty, Kevin D., and Richard V. Ericson. 2000. The surveillant assemblage. The British journal of sociology 51(4): 605-622.

Harvey, David. 2005. A brief history of neoliberalism. Oxford: Oxford University Press.

Johnson, Kevin. 2007. Police brutality cases on rise since 9/11. USA Today, December 18. http://usatoday30.usatoday.com/news/nation/2007-12-17-Copmisconduct N.htm.

Jones, Jeffrey M. 2015. In U.S., Confidence in Police Lowest in 22 Year. Gallup, June 19. http://www.gallup.com/poll/183704/confidence-police-lowest-years.aspx.

Kindy, Kimberly and Kelly Kimbriell. 2015. Thousands dead, few prosecuted. The Washington Post, April 11. http://www.washingtonpost.com/sf/investigative/2015/04/11/thousands-dead-few-prosecuted/.

Knapp, Andrew. 2015a. Attorney: North Charleston police officer felt threatened before fatal shooting. The Post and Courier, April 6. http://www.postandcourier.com/article/20150406/PC16/150409558.

Knapp, Andrew. 2015b. North Carolina officer faces murder charge after video shows him shooting man in the back. The Post and Courier, April 7. http://www.postandcourier.com/article/20150407/PC16/150409468.

Koskela, Hille. 2002. "Cam Era"-the contemporary urban Panopticon. Surveillance \& Society 1(3): 292-313.

Laughland, Oliver and Jon Swaine. 2015. "I dream about it every night": what happens to Americans who film police violence?. The Guardian, August 17. http://www.theguardian.com/us-news/2015/aug/15/filming-police-violence-walter-scottmichael-brown-shooting.

Lawrence, Regina G. 2000. The politics of force: Media and the construction of police brutality. Berkeley: University of California Press.

Lyon, David. 2006. The search for surveillance theories. Theorizing surveillance: The panopticon and beyond, edited by David Lyon, 3-20. London: Routledge.

Lyon, David. 2007. How did we get here? Criminal Justice Matters 68 (1): 4-5.

Main, Frank. 2016. Street cops say "ACLU effect" drives spike in gun violence. Chicago Sun Times, January 31. http://chicago.suntimes.com/politics/street-cops-say-aclu-effect-drives-spike-in-gun-violence/.

Mann, Steve, Jason Nolan, and Barry Wellman. 2002. Sousveillance: Inventing and Using Wearable Computing Devices for Data Collection in Surveillance Environments. Surveillance \& Society 1 (3): 331-355.

Mathiesen, Thomas. 1997. The viewer society: Michel Foucault's "Panopticon" revisited. Theoretical Criminology 1(2): $215-34$.

Miller, Kirk. 2016. The Politics of Policing: Between Force and Legitimacy. Sociology of Crime, Law and Deviance 21: $257-276$. 
Mitchell, David. 2016. Woman recording officers during protest arrests sues Denver police for taking her cellphone. Fox31 Denver, March 28. http://kdvr.com/2016/03/28/woman-recording-officers-during-protest-arrests-sues-denver-policefor-taking-her-cell-phone/.

Murakami Wood, David. 2007. Beyond the Panopticon? Foucault and surveillance studies. In Space, Knowledge and Power: Foucault and Geography, edited by J. W. Crampton and S. Elden. Burlington, VT: Ashgate, 245-263.

Mydans, Seth. 1991. Tape of Beating by Police Revives Charges of Racism. New York Times, March 7. Available at: http://www.nytimes.com/1991/03/07/us/tape-of-beating-by-police-revives-charges-of-racism.html.

Mydans, Seth, Richard W. Stevenson and Timothy Egan. 1991. Videotaped Beating by Officers Puts Full Glare on Brutality Issue. New York Times, March 18. Available at: http://www.nytimes.com/1991/03/18/us/seven-minutes-los-angelesspecial-report-videotaped-beating-officers-puts-full.html.

Pew Research Center. 2014. Mobile Technology Fact Sheet, Pew Research Center, http://www.pewinternet.org/factsheets/mobile-technology-fact-sheet/, last accessed February 62015.

Pew Research Center. 2015. Device ownership over time, Pew Research Center, http://www.pewinternet.org/datatrend/mobile/device-ownership/ last modified October 29, 2015.

Pengelly, Martin. 2015. Texas officer suspended after pool party video shows him pulling gun on teens. The Guardian, June 8 . http://www.theguardian.com/us-news/2015/jun/07/youtube-texas-police-officer-pool-party-arrests.

Phillip, Abby. 2015. Woman who posted video of officer punching a suspect becomes target of Miami police union. The Washington Post, August 14. https://www.washingtonpost.com/news/post-nation/wp/2015/08/14/woman-whorecorded-officer-punching-a-suspect-becomes-target-of-miami-police-union/?tid=sm fb.

Police Executive Research Forum (PERF), and United States of America. 2013. Policing and the Economic Downturn: Striving for Efficiency is the New Normal. Washington, DC: Police Executive Research Forum.

Portokalidis, Georgios, Philip Homburg, Kostas Anagnostakis, and Herbert Bos. 2010. Paranoid Android: versatile protection for smartphones. In Proceedings of the 26th Annual Computer Security Applications Conference, 347-356. ACM.

Rappaport, John. 2017. How Private Insurers Regulate Public Police. Harvard Law Review 130 (6): 1539-1614.

Sanburn, Josh. 2015. Eric Garner Witness Ramsey Orta Has Regrets One Year Later. Time, July 16. http://time.com/ramsey-ortaeric-garner-video/.

Sanchez, Ray. 2015. Chicago mayor: Anti-police backlash makes officers "fetal". CNN, October 16. http://www.cnn.com/2015/10/16/us/rahm-emanuel-police-comments/index.html.

Schmidt, Michael S. and Matt Apuzzo. 2015. FBI Chief Links Scrutiny of Police with Rise in Violent Crime. The New York Times, October 23. http://www.nytimes.com/2015/10/24/us/politics/fbi-chief-links-scrutiny-of-police-with-rise-inviolent-crime.html.

Schwirtz, Michael and Aaron Edwards. 2012. Police Shoot Man in Midtown, and Tourists Reach for Cameras. The New York Times, August 11. http://cityroom.blogs.nytimes.com/2012/08/11/police-shoot-man-near-times-square-and-touristsreach-for-cameras/.

Selwyn, Neil. 2004. Reconsidering political and popular understandings of the digital divide. New Media \& Society 6(3): $341-362$.

Shoichet, Catherine E., Berlinger, Joshua and Almasy, Steve. 2016. Alton Sterling shooting: Second video of deadly encounter emerges. CNN, July 6. http://www.cnn.com/2016/07/06/us/baton-rouge-shooting-alton-sterling/.

Silva, Daniella. 2015. Walter Scott Shooting: Dash Cam Video From Traffic Stop is Released. NBC News, April 9. http://www.nbcnews.com/storyline/walter-scott-shooting/dash-cam-video-shows-walter-scott-fleeing-fatal-shootingmichael-n338786.

Tsui, Lokman. 2003. The Panopticon as the Antithesis of a Space of Freedom Control and Regulation of the Internet in China. China information 17(2): 65-82.

Wang, Alan. 2014. Witnesses upset over Antioch arrest, police confiscating cellphones. ABC7 News, August 8th. http://abc7news.com/news/witnesses-upset-over-antioch-arrest-police-taking-cellphones/249975/.

Weber, Lara. 2015. The power of video and police use of force. Chicago Tribune, December 28. http://www.chicagotribune.com/ct-video-police-shootings-excessive-force-perspec-12xx-20151228-story.html. 